\title{
Research Methods Coverage in Medical and Health Science Curricula in Nepal
}

Simkhada P1-6, van Teijlingen E-9, Pokharel T10-13, Devkota B ${ }^{14-15}$ and Pathak RS 16-17

1Senior Lecturer in International Health, School of Health and Related Research (ScHARR), University of Sheffield, Sheffield, UK

${ }^{2}$ Honorary Lecturer, University of Aberdeen, UK.

3Visiting Fellow, Bournemouth University, UK.

${ }^{4}$ Adjunct Faculty- Datta Meghe Institute of Medical Sciences (Deemed University) Nagpur, India

5Visiting Professor, Manmohan Memorial Institute of Health Science, Tribhuvan University, Nepal.

${ }^{6}$ Visiting Professor, Nobel College, Pokhara University, Kathmandu, Nepal.

${ }^{7}$ Professor, School of Health \& Social Care, Bournemouth University, Bournemouth, UK.

${ }^{8}$ Honorary Visiting Professor, London Metropolitan University, London.

${ }^{9}$ Honorary Professor, University of Aberdeen, UK.

10Deputy Director of Studies, Nepal Administrative Staff College, Kathmandu Nepal

${ }^{11}$ General Secretary, Population Association of Nepal (PAN), Kathmandu Nepal

12Board Member, Transcultural Psychosocial Organization (TP0), Kathmandu Nepal

${ }^{13}$ Managing Editor, Journal of Management and Development Studies

${ }^{14}$ Reader-Faculty of Education, Kritipur Campus Tribhuvan University Kathmandu Nepal

15Director- Development Resource Centre, Kathmandu Nepal

16Professor and Head of Central Department of Population Studies, Tribhuvan University Kathmandu Nepal

17President, Population Association of Nepal (PAN), Kathmandu Nepal

Chief Editor: Dr. Brijesh Sathian

Technical Editor : Dr. Nishida Chandrasekharan

Formatting Editor: Bedanta Roy
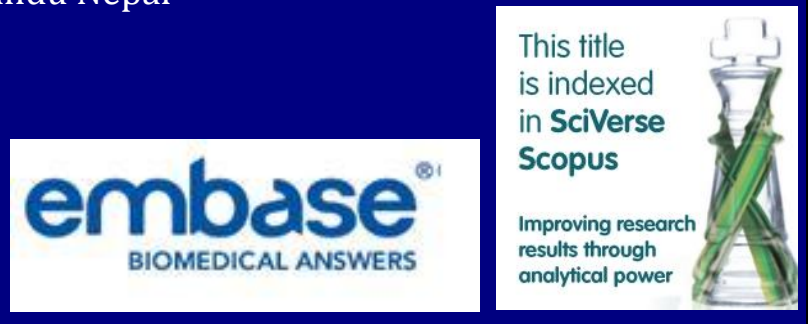

\section{Editorial}

\section{Correspondence Author:}

Dr Padam Simkhada

School of Health and Related Research (ScHARR)

University of Sheffield Regent Court

30 Regent Street

Sheffield S1 4DA

Email: p.simkhada@sheffield.ac.uk

\section{Introduction}

The question of what research component should be incorporated in medical and health science curricula is still contested. In the past few decades, there has been a trend of including a research component in medical and health science curricula to increase students' interest in conducting research and practice evidence-based medicine after their graduation $^{1}$. 
There is wide-ranging inequity in access to health care between the developed and developing countries, which is matched by unequal distribution of health information ${ }^{2}$. Access to the world's collective knowledge, primarily in health sciences and medicine is essential in order to create strong social, economic and technical infrastructures ${ }^{3}$. Access to research information is essential to strengthen practice, to empower local experts to find solutions to health problems and to encourage evidence-based practice. Evidence-based practice is important to deliver high quality care. But, lack of research literature is the most serious obstacle for health professionals and researchers in the developing world. According to a recent World Health Organization (WHO) survey of the 75 countries with a Gross National Product per capita per year of less than US $\$ 1,000$, $56 \%$ of medical institutions have had no subscriptions to journals over the last five years ${ }^{4}$.

Despite the enormous disease burden in Nepal, research is often viewed as an expenditure rather than an investment. Moreover, case studies from Nepal, Bangladesh, and Pakistan report that the bulk of government funding for research goes towards training, salaries, and infrastructure, resulting in research projects being largely funded (and influenced) by external donors ${ }^{5}$. Until recently, most health researchers in Nepal worked individually rather than in institutions.

Nepal has made great progress in health sciences and medical education, e.g. ten Medical Colleges have been established and quite a few are on the pipeline. There are more than 40 Nursing Colleges (both in private and public sectors) and an equal number of other health science colleges which provide health-related courses (e.g., Public Health, Pharmacy and Radiography) are currently functioning in Nepal. There are about 5,000 medical and health sciences students enrolled in those colleges each year and some 1,500 staff are directly involving in their teaching.

Despite this increase in institutions, the overall research environment is still poor ${ }^{6}$. The trend of Nepal-related research publications made by the Nepali researchers in peer-reviewed journals shows quite a limited number of publications compared to their non-Nepali counterparts. The number of publications seems lower in the Government University compared to private universities ${ }^{7}$. The use of evidence-based information in higher education is a must for addressing health-related problems but Nepal's higher education institutions' staff lack knowledge as well as resources for utilising research published even in free and low-priced journals ${ }^{8}$.

Many factors such as poor structural environment and lack of staff, financial and physical resources, might have contributed to inadequate focus on health science research. In addition, limited or no access to research information, particularly the electronic databases, could be one of the main reasons behind a poor research environment in Nepal. Because of expensive subscription fees and complicated licensed agreements, many medical schools and other higher education institutions in Nepal are unable to subscribe the health sciences related journals. This may be supported by inadequate awareness and interest among the health science academics. As a result, many researchers, university teachers and research students in Nepal often have little or no access to the published research literature6. Similarly, health research in Nepal is characterized by weak institutional infrastructures, inadequate funding, the consequent isolation and insularity of a research community against which ideas can be exchanged, leading to an insignificant contribution to the world's knowledge pool. The capacity to absorb scientific and technical knowledge is often weak in Nepal, leading to low levels of scientific output and further underdevelopment.

Limited research8 and our own experiences suggest that many higher education institutions and their researchers including university teachers are not able to access even freely available research literature. Several Nepali postgraduate students from different health backgrounds, despite having strong academic competency, lack necessary knowledge and skills to access research literature, the kind of skills needed to do a proper systematic review ${ }^{9}$. In recent years, there has been several studies looking at the research components in undergraduate medical curriculum 1,10,11,12. This paper is of the first kind to review systematically medical or health science curricula at a national level in Nepal.

\section{Rationale}

As the Government of Nepal (GoN) has favoured liberalisation of the education market after the restoration of democracy in 1990, there have been some remarkable developments partly through private involvement in education system. As the result many private institutions now offer higher education in health and medical sciences. With the growing number of institutions, it timely to examine research curricula they have adopted, especially focusing on the access to research literature and its utilisation.

Human resources for health services are key factors if Nepal is to achieve the targets of the MDGs (Millennium Development Goals) health. This article contributes to building the capacity of human resources for health services through promoting their research capacity. Analysing the research component in health science curricula and practices of evidence-based research information in teaching strategy enhances the skills and service delivery capacity of health workers.

\section{Aims and Objectives}

This contents analyses aims to analyse the coverage of research methodology components in the curricula of health sciences in higher education and the access to research literature. It also compares the contents of research methodology and access of research to research literatures by level (undergraduate/post-graduate) and by courses. Finally, it identifies gaps in curricula specific to 
research methodology and research literature access.

\section{Methodology}

The content analysis was completed in three stages development of content analysis tool (CAT), scanning the curriculum of all universities in health sciences and completing the CAT matrix, and comparing and contrasting different indicators (see below). The CAT was developed through a workshop and consultation meeting with project partners, key stakeholders and academics, it covered the major components of research methodology courses. CAT reflects the major components of a course - course duration, weighting, major research contents, access to theory and practical, teaching hours and assessment and/or exam.

The CAT matrix summary compared different universities and courses. A list of major ten contents, a standard research methodology course should have, is derived from international standard course. The same matrix is used to evaluate, compare and identify the gaps in health science curricula of different health institutions.

Box 1 Research components in curricula

Literature review
Research design - qualitative/quantitative
Statistics
Sampling
Ethical consideration in research
Proposal writing
Citation and referencing
Systematic review- e.g. meta analysis
Data analysis
Data analysis software - e. g. SPSS, Epi Info, SAS, STATA

This study analysed published curricula provided by the each university. Some curricula have detail specification of the courses with all information available while others are less structured. For those less structured courses the study team has recalculated the weights synthesising entire course contents.

\section{Analysis}

The review is in two sections: first research methodology courses in the curriculum of each programme are reviewed. This includes assessing the coverage of research methodology, weighting and teaching hours allocated. While assessing the contents of research methodology, we have also reviewed whether there are research methodology related contents in other courses than the research methodology course and they have been duly incorporated in the analysis. The second section is more specific to access of research literature in research methodology courses. Curricula are duly examined whether they have mentioned the techniques of accessing the research literature, use of literature database and methods of systematic review.

\section{Findings}

This analysis included undergraduate (Bachelor) and postgraduate (Master) courses. The reason behind was that the courses below undergraduate level were less research oriented as elsewhere and the courses above postgraduate were more research based which have no obvious reason to include in the analysis.

Curricula of 105 different programmes were reviewed. The number of programmes at Master's level (74) was more than double than that of Bachelor level (31). Tribhvuan University had the highest number of programmes in health sciences (37) followed by BP Koirala Institute of Health Health Sciences (33) and Kathmandu University (24). Pokhara University had no Master's programme running at the time of our review (Table 1).

\section{Table 1: Course/Programme included in content analysis}

\begin{tabular}{|l|c|c|c|c|c|c|}
\hline Level & TU & KU & PoU & PU & $\begin{array}{c}\text { BPKI } \\
\text { HS }\end{array}$ & Total \\
\hline $\begin{array}{l}\text { Bachelor } \\
\text { level }\end{array}$ & 11 & 4 & 6 & 4 & 6 & 31 \\
\hline Master level & 26 & 20 & 0 & 1 & 27 & 74 \\
\hline Total & 37 & 24 & 6 & 5 & 33 & 105 \\
\hline
\end{tabular}

Legend: TU Tribhuvan University; KU Kathmandu University; PoU Pokhara University; PU Prubanchal University ; BPKIHS BP Koirala Institute of Health Science

\section{Research Methodology in Undergraduate Programmes}

Tribhuvan University has offered the highest number of programmes (11) at undergraduate level. Pokhara University and BPKIHS have offered six programmes while $\mathrm{KU}$ and $\mathrm{PU}$ have offered four undergraduate programmes. Bachelor of Science in Nursing is a common programme offered by all institutions while programmes in Public Health and Pharmacy are offered by most of the institutions. TU, KU and BPKIHS have also offered some clinical and laboratory-based programmes at undergraduate level such as MBBS, BMLT and BDS.

One finding is that similar research methods courses are offered in for example, BSc in Nursing and BSc in Public Health. A separate course in research methodology is offered in Nursing, Public Health, Pharmacy and Dentistry. Basic contents of research methodology - research process, literature review, data collection, report writing and basic statistics - are introduced where separate course in research methodology is offered.

The curricula of Public Health and Nursing are more structured and cover more contents in research methodology than other undergraduate programmes. However, weighting (percentage of research methodology courses - theory and practical- in total teaching hours of the particular course in the entire course cycle) varies from as low as $1 \%$ (MBBS) to over 22\% (Public Health) at Bachelor level. The weighting of research methodology in nursing curricula varies between $4 \%(\mathrm{PU})$ to $14 \%$ (PoU), while the 
weighting in public health varies between 14 and 23\%. In Pharmacy, Dentistry, Lab technology, Ophthalmology and Biochemistry- the weighting varies between 2 and $10 \%$.

Table 2 Example Contents of Research Methodology in Undergraduate Programmes

\begin{tabular}{|c|c|c|c|c|c|}
\hline Name of Programme & TU & KU & PoU & PU & BPKIHS \\
\hline BSc Nursing & $8 \%$ & $4.52 \%$ & $14 \%$ & $4.1 \%$ & \\
\hline Literature review & $\sqrt{ }$ & $\sqrt{ }$ & $\sqrt{ }$ & $\sqrt{ }$ & \\
\hline $\begin{array}{l}\text { Research design - } \\
\text { qualitative/quantitative }\end{array}$ & $\sqrt{ }$ & $\sqrt{ }$ & $\sqrt{ }$ & $\sqrt{ }$ & \\
\hline Statistics & $\sqrt{ }$ & $\sqrt{ }$ & $\sqrt{ }$ & $\sqrt{ }$ & \\
\hline Sampling & $\sqrt{ }$ & $\sqrt{ }$ & $\sqrt{ }$ & $\sqrt{ }$ & \\
\hline $\begin{array}{l}\text { Ethical consideration in } \\
\text { research }\end{array}$ & $\sqrt{ }$ & & $\sqrt{ }$ & $\sqrt{ }$ & \\
\hline Writing up proposal & $\sqrt{ }$ & $\sqrt{ }$ & $\sqrt{ }$ & $\sqrt{ }$ & \\
\hline \multicolumn{6}{|l|}{$\begin{array}{l}\text { Citation and } \\
\text { referencing }\end{array}$} \\
\hline \multicolumn{6}{|l|}{$\begin{array}{l}\text { Systematic review/ } \\
\text { meta analysis }\end{array}$} \\
\hline Data analysis- & $\sqrt{ }$ & $\sqrt{ }$ & $\sqrt{ }$ & $\sqrt{ }$ & \\
\hline Data analysis software & & & & $\sqrt{ }$ & \\
\hline Total Score & 7 & 6 & 7 & 8 & \\
\hline BPH & $14 \%$ & & $20 \%$ & $22.45 \%$ & \\
\hline Literature review & $\sqrt{ }$ & & $\sqrt{ }$ & $\sqrt{ }$ & \\
\hline $\begin{array}{l}\text { Research design - } \\
\text { qualitative/quantitative }\end{array}$ & $\sqrt{ }$ & & $\sqrt{ }$ & $\sqrt{ }$ & \\
\hline Statistics & $\sqrt{ }$ & & $\sqrt{ }$ & $\sqrt{ }$ & \\
\hline Sampling & $\sqrt{ }$ & & $\sqrt{ }$ & $\sqrt{ }$ & \\
\hline $\begin{array}{l}\text { Ethical consideration in } \\
\text { research }\end{array}$ & $\sqrt{ }$ & & $\sqrt{ }$ & $\sqrt{ }$ & \\
\hline Writing up proposal & $\sqrt{ }$ & & $\sqrt{ }$ & $\sqrt{ }$ & \\
\hline $\begin{array}{l}\text { Citation and } \\
\text { referencing }\end{array}$ & $\sqrt{ }$ & & & & \\
\hline \multicolumn{6}{|l|}{$\begin{array}{l}\text { Systematic review/ } \\
\text { meta analysis }\end{array}$} \\
\hline Data analysis & $\sqrt{ }$ & & $\sqrt{ }$ & $\sqrt{ }$ & \\
\hline Data analysis software & $\sqrt{ }$ & & $\sqrt{ }$ & $\sqrt{ }$ & \\
\hline Total Score & 9 & & 8 & 8 & ? \\
\hline MBBS & $0.90 \%$ & $2.36 \%$ & & & \\
\hline \multicolumn{6}{|l|}{ Literature review } \\
\hline $\begin{array}{l}\text { Research design - } \\
\text { qualitative/quantitative }\end{array}$ & & $\sqrt{ }$ & & & \\
\hline Statistics & $\sqrt{ }$ & $\sqrt{ }$ & & & \\
\hline Sampling & $\sqrt{ }$ & $\sqrt{ }$ & & & \\
\hline \multicolumn{6}{|l|}{$\begin{array}{l}\text { Ethical consideration in } \\
\text { research }\end{array}$} \\
\hline \multicolumn{6}{|l|}{ Writing up proposal } \\
\hline \multicolumn{6}{|l|}{$\begin{array}{l}\text { Citation and } \\
\text { referencing }\end{array}$} \\
\hline \multicolumn{6}{|l|}{$\begin{array}{l}\text { Systematic review/ } \\
\text { meta analysis }\end{array}$} \\
\hline Data analysis & $\sqrt{ }$ & $\sqrt{ }$ & & & \\
\hline Data analysis software & $\sqrt{ }$ & $\sqrt{ }$ & & & \\
\hline Total Score & 4 & 5 & & & \\
\hline
\end{tabular}

Regarding contents, most programmes have four to six elements of our indicators, a few programmes have seven to nine elements and none has all elements. Public Health course offered by TU has the highest (9/10) elements; it missed out systematic reviewing. While two institutions (PoU and PU) miss out citation and referencing and systematic review. Many others (e.g. Medicine, Dentistry, Lab technology and Ophthalmology) have not introduced the topic of ethics in health research. The study finds a common gap in citation and referencing and systematic review in all curricula. Lab based and clinical programmes have less spelled out on research methodology in their curricula.

Table 3 Example of contents of Research Methodology in Postgraduate Programmes

\begin{tabular}{|c|c|c|c|c|c|}
\hline Name of Programme & TU & KU & PoU & PU & BPKIHS \\
\hline MPH & $30 \%$ & & & $34 \%$ & \\
\hline Literature review & $\sqrt{ }$ & & & $\sqrt{ }$ & \\
\hline $\begin{array}{l}\text { Research design - } \\
\text { qualitative/quantitative }\end{array}$ & $\sqrt{ }$ & & & $\sqrt{ }$ & \\
\hline Statistics & $\sqrt{ }$ & & & $\sqrt{ }$ & \\
\hline Sampling & $\sqrt{ }$ & & & $\sqrt{ }$ & \\
\hline $\begin{array}{l}\text { Ethical consideration in } \\
\text { research }\end{array}$ & $\sqrt{ }$ & & & $\sqrt{ }$ & \\
\hline Writing up proposal & $\sqrt{ }$ & & & $\sqrt{ }$ & \\
\hline $\begin{array}{l}\text { Citation and } \\
\text { referencing }\end{array}$ & & & & & \\
\hline $\begin{array}{l}\text { Systematic review/ } \\
\text { meta analysis }\end{array}$ & & & & & \\
\hline Data analysis & $\sqrt{ }$ & & & $\sqrt{ }$ & \\
\hline Data analysis software & $\sqrt{ }$ & & & $\sqrt{ }$ & \\
\hline Total Score & 8 & & & 8 & \\
\hline MN & $13.50 \%$ & & & & \\
\hline Literature review & $\sqrt{ }$ & & & & \\
\hline $\begin{array}{l}\text { Research design - } \\
\text { qualitative/quantitative }\end{array}$ & $\sqrt{ }$ & & & & \\
\hline Statistics & $\sqrt{ }$ & & & & \\
\hline Sampling & $\sqrt{ }$ & & & & \\
\hline $\begin{array}{l}\text { Ethical consideration in } \\
\text { research }\end{array}$ & & & & & \\
\hline Writing up proposal & $\sqrt{ }$ & & & & \\
\hline $\begin{array}{l}\text { Citation and } \\
\text { referencing }\end{array}$ & & & & & \\
\hline $\begin{array}{l}\text { Systematic review/ } \\
\text { meta analysis }\end{array}$ & & & & & \\
\hline Data analysis & $\sqrt{ }$ & & & & \\
\hline Data analysis software & $\sqrt{ }$ & & & & \\
\hline Total Score & 7 & & & & \\
\hline
\end{tabular}

\section{Research Methodology in Postgraduate Programmes}

A total of 74 postgraduate programmes were offered in five institutions. BPKIHS had the highest number of postgraduate programmes $(n=27)$, followed by TU (26), while Pokhara University had not offered any postgraduate programme in health sciences at the time of study. Similarly at undergraduate level, programmes could be classified into two broad groups: (a) general health sciences (Nursing, Public Health and Pharmacy); and (b) lab-based and clinical (MDs).

As expected, postgraduate programmes in general health sciences had better coverage of research methodology than undergraduate programmes. Within the postgraduate level the weighting of research methodology varied between 13 and $34 \%$ across the disciplines. Public Health courses had the highest weighting of research methodology whereas Nursing the least. Research methodology contributed 30 to $33 \%$ of total course weights in Public Health among five institutions while the proportion in Nursing stayed much lower namely between 13 and 15\%. 
Regarding the contents, seven to eight elements of our indicators were mentioned in the curricula. None of the curricula had mentioned citations and referencing or conducting systematic review. In case of lab-based and clinical programmes, no structured curriculum was available. However, the latter courses had incorporated a mandatory dissertation during the course cycle.

\section{Access to Research Literature}

It is interesting to note that most of the research methodology curricula have mentioned literature review, problem identification and writing a proposal. But they have failed to introduce accessing research literature in their curricula. A few curricula spelled out the source of webbased research literature, such as PubMed, HINARI, Medline or Pop-line but they failed to introduce the ways of accessing and utilising them. Nursing and Public Health curricula have introduced at least a few sources of electronic research literature but have not mentioned about the ways of accessing them.

\section{Discussion}

Higher education institutions in Nepal have been offering different types of health sciences programmes over the last few decades. With the growing number of education institutions, the range of programmes has also increased. Currently, five higher education institutions - TU, KU, PU, PoU and BPKIHS are providing health sciences course at undergraduate and graduate level.

TU being the leading university to offer most of health science programmes, there is observable influence in the curriculum contents and design of the remaining four institutions. However, a variation is observed in structure of curriculum within and between institutions. The curricula of Pokhara University are better designed and recent compared to other while the curricula of TU are less revised and comparatively old. Curricula in general health sciences are detailed and favourable to research methodology contents.

\section{Conclusions \& Recommendations}

Most of curricula contain basic statistics, data analysis package and introductory contents of research methodology. These are important assets for improving access to research literature. Recently introduced programmes, for example Public Health and Nursing in PU and PoU, have better research methodology contents and are more comprehensive in design.

There are some observed gaps in the health science curricula - a) dissimilar weighting within and across the disciplines; b) dissimilar curricula structure within and between institutions; c) omission of contents on ethical consideration, citation and referencing and systematic review; d) access to research literature; and e) less structured and detailed curricula of clinical and lab based programmes.
The study recommends a number of initiatives to improve the existing higher education curricula of health sciences in Nepal. Our key recommendations are that higher education institutions in Nepal need to review, where necessary revise existing health science curricula to strengthen their research methodology contents. Similarly, curricula should include more contemporary issues in research methodology training. The curricula should include clear instructions to students on how to access the most-up-to-date research literature and how to appraise the research articles.

\section{Acknowledgments}

We like to thank the local coordinators:

Janet Ashwell, Lalipur Nursing College, Kathmandu; Prof Paras K. Pokharel at School of Public Health \& Community Medicine, BP Koirala Institute of Health Sciences;

Dr Shyam Lohni, Nobel College, Pokhara University, Kathmandu

Dr Suraj Maratha, MMIHS, Kathmandu Nepal

Dr Dayaram Lamsal Chitwan Medical College, Chitwan

Dr Shishir Gokhale, and Dr Brijesh Sathian Manipal College of Medical Sciences, Pokhara

We like to express our appreciation to all participants who gave up their time to review the curricula and, last but not least, the British Council and DELPHE for funding this work.

\section{References:}

1. Sreedharan J. Introduction of a Research component in the undergraduate medical curriculum - Review of a trend; Nepal J Epidemiol 2012;(3):200-4

2. Katikireddi SV. HINARI: bridging the global information divide, BMJ; 2004; 328:1190-1193

3. Kirsop B and Chan L. Transforming access to research literature for developing countries, Serials Review; 2005; 21 (4): 246-254

4. Aronson, B. Improving Online Access to Medical Information for Low-Income Countries, New Eng J Med 2003; 350(10): 966-968.

5. Sadana R, D'Souza C, Hyder AA, Mushtaque A and Chowdhury R. Importance of health research in South Asia, BMJ; 2004; 328: 826-830

6. Arunachalam, S. Information for Research in Developing Countries - Information Technology, a Friend or Foe, Int Information and Lib Review; 2003; 35(2-4): 133-147.

8. Acharya GP. Health Research in Medical Colleges, KUMJ 2003; 2, No. 2, Issue 6, 85-88

9. van Teijlingen, E.R., Simkhada, B, Ireland J, Simkhada P and Bruce J. Evidence-based health care in Nepal: The importance of systematic reviews, Nepal J Epidemiol 2012; 1(4): 114-118.

10. WHO. Review of Preventive and Social Medicine / community Medicine / Community Health Curriculum for Undergraduate Medical Education; Report of the Expert Group Meeting SEARO, New Delhi, India, 27-28 August 2009. Accessed on July 2013; Available 
http://apps.searo.who.int/pds_docs/B4482.pdf

11. Simkhada P, Baral YR, van Teijlingen E. Health and Medical Research: A Bibliometric Review, Asia-Pac J Publ Health 2012; 22(4): 492-500. Web address http://aph.sagepub.com/content/22/4/492.full.pdf+html 12. World Federation for Medical Education. International standards in medical education: assessment and accreditation of medical schools educational programmes. A WFME position paper. Med Educ 1998; 32: 549-58.

13. Deo MG. Need for research oriented medical education in India. Indian J Med Res 2009; 130: 105-7.

\section{Article Information}

\section{Article history}

\begin{tabular}{|l|l|}
\hline Received & $20^{\text {th }}$ August 2013 \\
\hline Received in revised form & $1^{\text {rd }}$ September 2013 \\
\hline Accepted & $20^{\text {rd }}$ September 2013 \\
\hline
\end{tabular}

